посіб.] / І. М. Богданова. - Одеса : ТЕС, 2000. - 148 с. 3. Енциклопедія педагогічних технологій та інновацій / авт.-уклад. Н. П. Наволокова. - Х. : Вид. група «Основа», 2009. - 176 с. - (Серія «Золота педагогічна скарбниця»). 4. Зайчук В. О. Сучасні педагогічні технології: дидактичноінноваційний аспект / В. О. Зайчук, А. С. Нісімчук, Н. В. Тарадюк. - Луцьк : ПВД «Твердиня», 2009. - 312 с. 5. Кларин М. В. Инновации в мировой педагогике: обучение на основе исследования, игры и дискуссии (анализ зарубежного опыта) / М. В. Кларин. - Рига : НПЦ «Эксперимент», 1998. - 180 с. 6. Підласий І. П. Практична педагогіка або три технології: інтерактивний підручник для педагогів ринкової системи освіти / І. П. Підласий. - К. : ВД «Слово», 2004. - 616 с. 7. Селевко Г. К. Энциклопедия образовательных технологий : у 2 т./ Г. К. Селевко. - М. : НИИ школьных технологий, 2006. - Т.18. - 16 с. 8. Ягупов В. В. Педагогіка : [навч. посіб.] / В. В. Ягупов. - К. : Либідь, 2003. - 560 с.

УДК $37.013 .42 \ll 185 / 190 »(477.75)$

E. С. Сімакова, acniрант,

Свпаторійський інститут соиіальних наук РВНЗ «Кримський гуманітарний університет» (м. Ялта)

\title{
ЗАГАЛЬНА ХАРАКТЕРИСТИКА СТАНОВЛЕННЯ СОЦАЛЬНОЇ РОБОТИ В КРИМУ (ДРУГА ПОЛОВИНА ХІХ - ПОЧАТОК ХХ СТОЛІТТЯ)
}

Сімакова Е.С. Загальна характеристика становлення соціальної роботи в Криму (друга половина XIX - початок XX століття).

У статті проаналізовано стан вивченості проблеми соціальної роботи в Криму в другій половині XIX - початку XX століття та надано іiі загальну характеристику: створення і функціонування соціальних установ. Автор характеризує основні напрямки роботи земств, шкіл, притулків, установ опіки та піклування для неповнолітніх дітей, благодійних установ.

Ключові слова: соціальна робота, неповнолітні діти, соціальні установи в Криму в другій половини XIX - початку XX століття.

Симакова Е. С. Общая характеристика становления социальной работы в Крыму (вторая половина XIX - начало XX века).

В статье анализируется состояние изученности проблемы социальной работы в Крыму во второй половине XIX - начале XX в. и дается ее общая характеристика: создание и функционирование социальных учреждений. Автор описывает основные направления работы земств, школ, приютов, учреждений опеки и попечительства для несовершеннолетних детей, благотворительных учреждений.

Ключевые слова: социальная работа, несовершеннолетние дети, социальные учреждения в Крыму во второй половине XIX - начале XX в.

Simakova E. S. General characteristics of social work in the Crimea (in the second half of the nineteenth - early twentieth century).

The article analyzes the state of knowledge about the problem of social work in Crimea from the second half of XIX century to the early XX century and as well it gives its general characteristics, i.e. the creation and functioning of social institutions. The author describes the main working directions of district councils, schools, orphanages, institutions of guardianship and custody for minor children.

Key words: social work, minor children, social institutions in Crimea from the second half of XIX century to the early XX century.

Розбудовуючи нову систему освіти, маємо насамперед відроджувати національні історико-педагогічні традиції. Для сучасного етапу розвитку української держави характерним $\epsilon$ процес переоцінювання історичного досвіду, в якому $\epsilon$ ще багато недосліджених проблем. Зокрема, до них слід віднести низку питань, пов'язаних зі становленням та розвитком соціальних служб на Україні у часі нашого недалекого минулого. 
У результаті змін, що відбуваються в нашій державі, різко загострилася решта проблем, і це зажадало введення нової спеціальності - соціальна робота, і нової професії «соціальний педагог», але ця проблема не є абсолютно новою в історії освіти: соціальна робота 3 дітьми завжди була одним із напрямків роботи педагогів, тому що, на жаль, соціальні проблеми та питання супроводжували соціокультурну реальність українського суспільства задовго до офіційної появи професії соціальний педагог.

Актуальність теми визначається також тим, що звернення до історичних джерел досліджуваного періоду суттєво розширює наші уявлення, зокрема, про еволюцію освітньо-виховних систем у різноманітних соціальних службах України, які були організовані благодійними організаціями, окремими приватними особами, церквами й монастирями та державою, закономірності становлення соціальних служб в умовах соціально-політичних і культурних змін, що відбувалися в Україні, яка перебувала у складі Російської імперії.

Оскільки науково обгрунтована державна політика щодо розвитку соціальної діяльності робить в Україні лише перші кроки, особливого значення набувають історико-педагогічні дослідження з проблем організації соціальних служб у минулому.

Україна $\epsilon$ системою регіонів, кожен 3 яких має свої особливості, які зумовлені відмінністю географічного середовища, історичного та національного розвитку. Дослідження діяльності системи соціальних служб у регіональному аспекті має велике значення, особливо для Півдня Україні, де у минулому особливо гостро стояли питання допомоги неповнолітнім дітям через культурно-історичні та багатонаціональні характеристики. Не можна забувати, що через пізнання історії освіти свого регіону можна краще пізнати педагогічну спадщину всього народу та держави. Вивчення внеску кожної 3 регіональних культур у загальнодержавну скарбницю $\epsilon$ необхідним для збереження творчої спадщини, для майбутнього тієї чи іншої культури, культурного взаємообміну між народами.

Отже, актуальність дослідження зумовлена важливістю об'єктивного осмислення історичного досвіду; необхідністю критичного аналізу діяльності соціальних установ та соціально-педагогічної діяльності загальноосвітніх навчальних закладів Криму в XIX - на початку XX століття з метою обгрунтованого використання їхнього досвіду у процесі корекції та виховання неповнолітніх дітей з соціальними проблемами в сучасних умовах полікультурного Криму, можливістю прогнозування подальшого розвитку освіти для підвищення якості навчання й виховання підростаючих поколінь.

Здійснення наукового пошуку зумовило необхідність вивчення великої кількості архівних і літературних джерел, результатів дисертаційних досліджень. Стан системи розвитку освіти України, яка в XIX - на початку XX століття перебувала у складі Російської імперії, досліджувався І. Волковою, І. Зайченко, Н. Колядою, Л. Применко та іншими науковцями. Становлення педагогічної освіти в Україні, у тому числі соціальних закладів на XIX - початку XX століття висвітлено в наукових працях Л. Вовк, М. Гупана, Н. Дем'яненко, М. Свтуха, О. Сухомлинської, М. Ярмаченка та інших, які вважаємо підгрунтям дослідження соцільно-педагогічних закладів для дітей у Криму XIX - початку ХХ століття.

Однак, як засвідчує аналіз науково-педагогічної літератури, дисертаційних робіт, цілісного дослідження становлення соціальних служб у Криму XIX - початку XX століття здійснено не було. Соціальна педагогіка - молода наука, тому необхідно вивчати народний досвід у цій галузі, щоб сприяти розвитку соціально-педагогічної роботи на Україні. Так, не досліджено організацію, зміст навчально-виховного й коректувального процесу в соціальних закладах по роботі з неповнолітніми дітьми Криму, специфіку їх функціонування у зазначений період тощо. Аналіз значної кількості архівних i літературних джерел, що мають історико-педагогічне значення, надав змогу зробити висновок, що в Україні не здійснювалося цілісного фундаментального дослідження 3 проблем історії становлення та розвитку соціальних служб в Україні у другій половині 
XIX - на початку XX століття. Це питання не було предметом цілісного історикопедагогічного вивчення.

Отже, актуальність і недостатня наукова розробленість проблеми, потреба здійснення цілісного історико-педагогічного дослідження історії становлення та розвитку соціальних служб, їх системи та змісту виховання, здобутків, проблем, специфіки і традицій діяльності різнотипних соціальних служб державного та приватного спрямування в Південному регіоні України з метою творчого використання національного досвіду в сучасних умовах і зумовили необхідність відродження й втілення у практику кращих педагогічних ідей, здобутків та національно-освітніх традицій, які були притаманні українським соціальним навчально-виховним закладам другої половини XIX - початку XX ст.

Meта статmi - на базі опублікованих джерел і наукової літератури здійснити аналіз стану вивченості проблеми становлення соціальної роботи в Криму у другій половині XIX - початку XX століття.

Під час вивчення літературних джерел визначено, що основні проблеми періодизації історії соціальної роботи пов’язані з: 1) точкою відліку практики суспільної допомоги і взаємодопомоги; 2) виокремленням етапів допомоги і взаємодопомоги в Україні; 3) визначенням особливостей феномена допомоги і взаємодопомоги [3, с. 248].

У статті ми виокремлюємо такі основні етапи допомоги і взаємодопомоги в Україні: 1) архаїчний період; родоплеменні й суспільні форми допомоги і взаємодопомоги у слов'ян до X ст.; 2) період князівської й церковно-монастирської підтримки 3 X до XIII ст.; 3) період церковно-державної допомоги з XIV до другої половини XVII ст.; 4) період державної опіки з другої половини XVII ст. до другої половини XIX ст.; 5) період суспільної й приватної опіки з кінця XIX до початку XX ст.; 6) період державного забезпечення з 1917 р. до 1991 р.; 7) період соціальної роботи з початку 90-х рр. до нашого часу [5, с. 52].

Культурно-історична парадигма соціальної роботи дозволяє визначити такі особливості феномену допомоги і взаємодопомоги:

- має соціогенетичну зумовленість, представлену своєю історією й генезисом індивідуального розвитку в соціально-історичній перспективі;

- має історичні, матеріальні й діяльнісні форми існування зі своїми суб'єктами допомоги, об'єктами допомоги, ідеологією допомоги, що визначає його соціальногенетичну типологію як явища, процесу і феномену культури;

- становить собою те особливе «соціальне поле, де окреслюються різні типи взаємодій між суб'єктами зі своїми соціальними, етичними, економічними законами й принципами. Піклування про злидарів і юродство, інфатицид і організація дитячих притулків, навчання глухонімих і трудова допомога, добродійність і страхування - явища, які мають свою логіку історичного розвитку, свою систему існування, своє місце в історичному процесі;

- у процесі свого розвитку цей феномен знаходить інтерпретацію в структурних сценаріях і закріплений у масовій свідомості в мовних формах і структурах [4, с. 120].

У другій половині XIX ст., на відміну від XVIII, у підходах до ідеології допомоги виникає переоцінювання бачення проблематики клієнта. Якщо на ранніх етапах суспільної опіки нужденний становив певну цінність для окремої особистості - заступника, оскільки захист його був наглядною, матеріальною чеснотою перед обличчям Усевишнього, то тепер нужденний стояв перед державними інститутами, і саме вони визначали його необхідність у цій ролі. Та й сама людина оцінюється з нових критеріальних позицій як діяч, носій суспільно корисної праці. У цьому розумінні змінюються й ідентифікатори. Діяльність, праця, можливість або неможливість приносити користь - ось ті критерії, на яких базується новітня доктрина допомоги.

«Пристойність - непристойність» становить основний критерій «можливості неможливості» існування цього явища, що зумовлює іншу класифікацію клієнтів (їх типологія здійснюється не за принципами милостей духовних і тілесних, а за можливості 
або неможливості бути учасником спільної життєдіяльності в суспільстві). На основі таких підходів починають формуватися критерії типології особистості нужденного, коли його розглядають $з$ позицій і явищ соціальної норми й соціальної патології [3, с. 186].

Отже, у державній парадигмі допомоги починають домінувати поняття і значення іншого порядку. Теологічні підходи до особистості клієнта замінюються соцієтальними, а індивідуальна доля розглядається не в контексті вічності, а в контексті видимих потреб і проблем суспільства, його життєдіяльності, норм і цінностей. Усе це висуває певні принципи ідентифікації соціально необхідної поведінки, пов'язаної з нормою суспільних відносин, які узгоджені з оцінкою життєвого сценарію особистості.

У другій половині XIX ст. істотно змінюється управління соціальним захистом. Функції нагляду за суспільною опікою залишились за Міністерством внутрішніх справ; у більшості губерній його здійснювали земські та міські установи, що стали правонаступниками приказів суспільної опіки на місцях. Водночас у деяких губерніях, де ще не було земських установ, продовжували функціонувати прикази. Державна фінансова підтримка закладів опіки (на кінець XIX ст.) поступово набуває систематичного характеру. Згодом виокремлюються нові категорії непрацездатних осіб суспільної опіки: незаконнонароджені немовлята й підкидьки, що потребували загального та амбулаторного лікування, прокажені, хронічні хворі, божевільні, безробітні, сім'ї солдат, призваних на дійсну службу. Згідно з Лікарським статутом суспільна опіка мала стосуватися породіль, тимчасово безпритульних неповнолітніх, осіб, покусаних скаженими тваринами, алкоголіків [2, с. 93].

Земська система опіки була більш мобільною і прогресивною. У межах іiі компетенції перебували такі питання: розвиток освіти й запровадження всезагального навчання; опіка безпритульних дітей; організація медичного обслуговування; профілактика зубожіння; організація громадських робіт; соціально-економічна допомога селянству; юридична допомога.

Істотну роль у наданні соціальної допомоги відіграли також органи міського самоврядування (міські думи) та сільські громади, важливу роль відігравала приватна благодійність. Варто відзначити діяльність родин Терещенків, Ханенків, М. Дегтярьова, С. Могилевцева, Т. Гладинюка, Л. Бродського та інших. Родина українських промисловців та землевласників Терещенків на благодійність витратила майже 5 млн. крб., підтверджуючи тим самим девіз їхнього дворянського герба - «Прагнути до громадських справ». Художнє зібрання Терещенків лягло в основу Київського музею російського мистецтва та інших музеїв столиці $[1$, с. 25].

У цілому у другій половині XIX - початку XX ст. спостерігаються такі основні напрямки суспільної й наукової думки про сутність суспільної допомоги: теологічний, конфесіональний; правовий напрямок, теорія законодавства в соціальних питаннях; суспільна благодійність й опіка як культурно-історичний і соціально-політичний процес; «суспільна і професійна гігієна»; виховання й «виправне виховання»; система організацій допомоги; теорія страхування; теоретичні проблеми допомоги інвалідам; навчання спеціалістів; «піклування морально пропащих і патронат над випущеними 3 тюрем» [5, c. 76]. Кожен напрямок мав свою наукову традицію, свій підхід до розуміння сутності приватної та суспільної опіки, але вона була й логічним продовженням розвитку суспільної думки в цьому кластері пізнання, що базується на попередніх пізнавальних тенденціях.

\section{Література}

1. Вступ до соціальної роботи / за ред. Т.В. Семигіної, І.І. Миновича. - М. : Академвидав, 2005. - 304 с. 2. Сейко Н. А. Доброчинність поляків у сфері освіти України (XIX - поч. XX ст.). Київський учбовий округ : [монографія] / Н. А. Сейко. - Житомир : ЖДУ, 2006. - 318 с. 3. Очерки истории школы и педагогической мысли народов СССР. Конец XIX - начало XX в. / под ред. Э. Д. Днепрова, С. Ф. Егорова, Ф. Г. Паначина и др. - М. : Педагогика, 1991. - 448 с. 4. Розвиток народної освіти і педагогічної думки на Україні (X - початок XX століття): Нариси / М. Д. Ярмаченко (відп. ред.) та ін. - К. : Радянська школа, 1991. - 384 с. 5. Шушара Т. В. 
Розвиток жіночої освіти в Криму (XIX - початок XX століття) : автореф. дис. на здобуття наукового ступеня канд. пед. наук : 13.00.01 / Т. В. Шушара. - Ялта : РИО КГУ, 2006. -20 с.

\section{РОЗВИТОК ІМПЕРАТОРСЬКИХ УНІВЕРСИТЕТІВ ЯК СОЦІОКУЛЬТУРНИЙ ЧИННИК ЗАПОЧАТКУВАННЯ ВИЩОЇ ПЕДАГОГІЧНОЇ ОСВІТИ В УКРАЇНІ}

Сомбаманія Г. М. Розвиток імператорських університетів як соціокультурний чинник започаткування вищої педагогічної освіти в Україні.

Стаття присвячена висвітленню особливостей становлення імператорських університетів як джерел започаткування вищої педагогічної освіти в Україні. Особлива увага приділяється аналізу організації теоретичної та практичної складових педагогічної підготовки випускників класичного університету.

Ключові слова: класичний університет, організація педагогічної підготовки викладачів.

Сомбамания А.Н. Развитие императорских университетов как социокультурный фактор возникновения высшего педагогического образования в Украине.

Статья посвящена обобщению особенностей императорских университетов как источников зарождения высшего педагогического образования в Украине. Особое внимание уделяется анализу организации теоретического и практического аспектов педагогической подготовки выпускников классического университета.

Ключевые слова: классический университет, организация педагогической подготовки преподавателей.

Sombamaniya H. N. Development of imperial universities as a sociocultural factor of establishing of higher pedagogical education in Ukraine.

The article is devoted to summarizing the features of imperatorskiy universities as sources of origin of higher pedagogical education in Ukraine. Special attention is paid to the analysis of the organization of the theoretical and practical aspects of pedagogical teacher training of the graduates of classical university.

Key words: classical university, organization of pedagogical teacher training.

Сучасні реформаційні процеси в університетській освіті загалом та в галузі підготовки наукових та науково-педагогічних кадрів зокрема умотивовані глобальними соціальноекономічними та суспільно-політичними змінами. Відповідно, вони потребують історикосистемного підходу до їх вивчення задля визначення подальших перспектив розвитку освітньої галузі. Отже, актуалізується спрямування - від сучасного до майбутнього через минуле. Особливої ваги у зв'язку з цим набуває дослідження періоду становлення вищої педагогічної освіти в Україні, коли освітніми реформами 1802-1804 pp. i 1828-1835 pp. було започатковано відкриття класичних «імператорських» університетів.

Розроблення означеної проблеми започаткували відомі історики, філософи та історики педагогіки XIX ст.: І. Альошинцев, Д. Багалєй, В. Бузескул, М. Гербель, М. Лавровський, Є. Ліхачова, С. Рождественський, М. Халанський, Є. Шмід та ін. Процес педагогічної підготовки вчителя визначеного періоду досліджувався О. Бутягіним, Є. Князєвим, М. Кузьміним, М. Нечаєвою, Ф. Паначиним, Л. Юрченко та ін. Питання філософії освіти, сучасного реформування педагогічної освіти піднято у працях А. Алексюка, І. Зязюна, В. Лутая, М. Михальченка, Л. Нечепоренко. Історію розвитку педагогічної освіти проаналізовано такими науковцями, як Л. Вовк, М. Свтух, О. Глузман, Н. Дем'яненко, В. Майборода, О. Сухомлинська, М. Ярмаченко та ін.

Ураховуючи актуальність означеної проблеми, метою статті є висвітлення 